\title{
IPO Location as a Quality Signal: The case of Chinese developers
}

Wong, S. K., Wei, Q., and Chau, K. W.

Department of Real Estate and Construction, The University of Hong Kong

Suggested Citation:

Wong, S. K., Wei, Q., \& Chau, K. W. (2014). IPO Location as a Quality Signal: The Case of Chinese Developers. The Journal of Real Estate Finance and Economics, 49(4), 551-567.

URL: http://link.springer.com/article/10.1007/s11146-013-9441-0

DOI: $10.1007 / \mathrm{s} 11146-013-9441-0$ 


\title{
IPO Location as a Quality Signal: the case of Chinese developers
}

Wong, S. K., Wei, Q., and Chau, K. W.

Department of Real Estate and Construction, The University of Hong Kong

\begin{abstract}
A growing number of mainland Chinese real estate firms went public over the past decade. Some floated their shares in Hong Kong, while others were listed on mainland stock exchanges. This paper empirically examines the determinants of their initial public offering (IPO) location choice. Based on probit analysis, we found that developers with better unobserved quality are more likely to list in Hong Kong than in the mainland. State ownership, gearing ratio, and property market performance are other significant determinants of IPO locations. A further test shows that the degree of IPO underpricing is larger for firms listed in mainland China than those listed in Hong Kong. All these findings are consistent with the signaling hypothesis - good firms signal their quality to investors by listing in market with more stringent regulatory environment where other firms cannot afford to imitate.
\end{abstract}

Keywords: IPO, location, signaling, underpricing 


\section{INTRODUCTION}

Real estate development has played an important role in China's economic growth. With the opening up of China since the 1980s, more than 50 real estate developers in mainland China have made initial public offerings (IPOs) on either the Hong Kong stock exchange or the two mainland stock exchanges in Shanghai and Shenzhen. ${ }^{1}$ The former is a well-known international stock market established under British rule in the $19^{\text {th }}$ century, whereas the latter is a relatively new but fast-growing stock market under the so-called socialist market economic system. As of the end of 2011, the market capitalization of the Hong Kong stock exchange was US $\$ 2,300$ billion (world no.6), whereas the aggregate size of the two mainland exchanges was US\$3,400 billion (world no.5 and 12). In terms of capital raised in 2010, Hong Kong, Shenzhen, and Shanghai's stock exchanges were ranked the first, second, and fourth, respectively (New York was the third). ${ }^{2}$

Mainland firms were undoubtedly one of the key drivers of these fund-raising activities, and firms in the real estate sector were often the market focus. Regarding the choice of IPO locations, an article in Financial Times reported that "a number of privately owned Chinese property developers have opted to list in Hong Kong". ${ }^{3}$ But in the Data section, we will see that among 57 mainland developers, half of them floated their shares in Hong Kong and the other half stayed in the mainland market. What are the main reasons for their choices of IPO location? This paper attempts to answer this question. By focusing on real estate companies, we are able to use price indices in the private property market to account for changes in the market value of their underlying assets and test if property market conditions would alter their IPO location choice. It is important to note that our subject is always mainland developers, i.e.

\footnotetext{
1 "Mainland China" or simply "mainland" refers to China excluding Hong Kong.

2 Global IPO trends 2011, Ernst \& Young, page 4.

3 “Excellence plans HK listing", Financial Times, October 14, 2007.
} 
no Hong Kong developers are included.

Firm characteristics and stock market performance aside, we are particularly interested in whether the reputation of an IPO location matters. While some financial information is revealed through the IPO process, a firm often has private information on its asset quality or future prospects that cannot be credibly observed by potential investors. Listing in a reputable market is a way to convey such private information to investors. Comparing the Hong Kong and mainland markets, the former is regarded as more reputable because of its more mature legal system with stringent listing rules and enforcement. ${ }^{4}$ Firms listed in Hong Kong are subject to a higher degree of information disclosure so that investors there suffer less from asymmetric information. ${ }^{5}$ This gives incentives to high quality firms - those whose market value is likely to be underestimated by investors - to issue shares in Hong Kong in order to signal their unobserved quality. In contrast, low quality firms are better off conducting IPOs in mainland China in order to avoid disclosing their unobserved quality.

There is anecdotal evidence that the reputation of an IPO location matters. Some big mainland developers reportedly chose Hong Kong for their IPOs because its stock market would help them promote their image to the rest of the financial world. ${ }^{6}$ Of course, apart from reputation, developers also have other considerations before choosing their IPO locations. For example, they may prefer to list in a location with relatively better stock market sentiment or local property market conditions. Whether the developer is state or privately owned may also

\footnotetext{
${ }^{4}$ According to World Economic Forum, Hong Kong ranked the first in financial development due to its strong tax regime, highly developed infrastructure, etc., whereas mainland China ranked $19^{\text {th }}$. [please include the reference/website] The World Bank's governance indicators also show that Hong Kong scored much higher than mainland China in terms of regulatory quality, rule of law, and control of corruption (91-99.5 in Hong Kong vs 32.5-45 in mainland China) [please include the reference/website].

${ }^{5}$ The market was reportedly concerned about Mainland firms' corporate governance and financial reporting standard, especially when auditors unexpectedly quitted their jobs. Recently, a Mainland firm listed in Hong Kong said it could not provide the auditor with details because its business involves state secrets. Consequently, the Hong Kong regulator suspended its trading.

${ }^{6}$ Southern Metropolis Daily, August 28, 2007.
} 
matter. These factors will be accounted for when analyzing IPO location choices.

As the first step of analyzing IPO location choices, we need a measure of a firm's private information on unobserved quality. Ideally, it is a firm's expectations of its future, post-IPO performance, but this information is bound to be unknown or unreliable; otherwise, no information asymmetry between a firm and its prospective investors would have arisen. Without any reliable measure of ex ante performance, we constructed three proxies based on the unexpected component of a firm's post-IPO performance. Two of them are conventional measures of abnormal share price returns: the Sharpe Ratio and Jensen's alpha. They represent the risk-adjusted performance of a firm and are ex post measures of the firm's performance relative to that of the stock market. We assume that a firm's observed quality has been fully reflected by its initial stock price, so any future abnormal returns it earns could serve as a proxy for unobserved quality. The third proxy is the post-IPO abnormal profit return. It is defined as the residual component of return-on-asset that is not attributable to property market performance, ownership structure, or capital structure. It can be regarded as an ex post measure of a firm's unobserved operating performance.

In the second step, we used a Probit model to verify if the above proxies for a firm's unobserved quality impacted a firm's IPO location choice. Consistent with the signaling theory, we found that mainland developers with better unobserved quality were more likely to list in Hong Kong. In addition, some firm characteristics and market conditions also mattered. Developers with state ownership or less leverage (i.e., liabilities/assets ratio before IPOs) were more likely to conduct IPOs in mainland China. Property market conditions were also a factor: when mainland property prices increased, developers were more likely to conduct their IPOs in mainland China.

After the above analysis, we further tested if firms listed in different stock markets had 
distinct IPO underpricing patterns. The literature suggested that high quality firms may use IPO underpricing to signal their unobserved quality when there is information asymmetry (Welch, 1989; Allen and Faulhaber, 1989; Grinblatt and Hwang, 1989; Boulton et al., 2011). By implication, listing in a more reputable market should enable a firm to underprice less. To test this, we calculated an IPO underpricing ratio by using the offer price from each IPO's prospectus and the closing prices on days of each IPO. Consistent with the signaling theory, we found that developers listed in the mainland market, which suffers more from information asymmetry, had a larger degree of underpricing after controlling for stock market returns during their IPOs and other firm characteristics.

The rest of the paper proceeds as follows. Section 2 briefly reviews the literature on signaling and highlights the contributions of this paper. Section 3 describes the data and methodology to test two hypotheses. The main empirical results and their implications are discussed in Section 4, while the last section provides the concluding remarks.

\section{LITERATURE REVIEW}

Since Akerlof (1970) showed that some costly actions can mitigate the inefficiency arising from asymmetric information, the signaling idea has been applied to explain many phenomena in the financial market. First, when there is asymmetric information between insiders and outsiders of a firm, capital structure may signal a firm's unobserved quality or earnings (Leland and Pyle, 1977; Myers and Majluf, 1984). Second, it has been argued that offering more dividends may serve as a signal for a firm's higher unobserved quality (Bhattacharya, 1979; Brickley, 1983), although the empirical evidence is not always consistent (Lang and Litzenberger, 1989; Ofer and Siegel, 1987). Third, delays in converting convertible debt can signal a firm's good quality (Harris and Raviv, 1985; Ofer and Natarajan, 1987). 
Similar to the above literature, our study treats information asymmetry between a firm and prospective investors as an important real-world constraint that affects a firm's decision. In particular, we put forward that IPO location is another signaling device that a firm can use to reveal its unobserved quality. This has received theoretical support from Cheung and Lee (1995) and Fuerst (1998), who justified the preference for listing on a foreign stock exchange with a more stringent regulatory environment. However, empirical studies were scant, except these two: Blass and Yafeh (2001) found that high quality firms in Israel were more likely to conduct IPOs in the US than in Tel Aviv, whereas Yang and Lau (2010) showed that foreign firms conducing IPOs in the US did not show long-term underperformance. ${ }^{7}$ Our study provides a much cleaner empirical test of the signaling effect on IPO locations because we are comparing two stock markets in close proximity within one country. The Hong Kong and mainland markets are the most popular places for mainland firms to go public and yet have very distinct regulatory systems.

Our further test of the signaling idea is also highly relevant to the IPO underpricing literature. While IPO underpricing has been examined by a lot of empirical studies (Ibbotson, 1975; Ritter, 1984; Ritter, 1991; Ibbotson, Sindelar, and Ritter, 1988; Kennedy et al., 2006), no attempt was made to study IPO underpricing in different IPO locations. Our test will build on the signaling argument that a high quality firm should signal its quality by underpricing its IPO shares and recoup the cost of this signal after the stock market has confirmed its good quality (Welch, 1989, Allen and Faulhaber, 1989, and Chemmanur, 1993). The degree of underpricing should depend on how much information asymmetry a market exhibits. This contrasts with Tian's (2011) argument that mainland IPO underpricing was mainly caused by government intervention. Our findings would also contribute to the literature on corporate governance in

\footnotetext{
${ }^{7}$ Cross-listings have been widely examined in the literature (Merton, 1987; Baker et al, 2002; Reese and Weisbach, 2002; Doidge, 2004; etc.), but they are less relevant to our study which deals with a firm's first IPO location choice.
} 
emerging markets, such as that of China (Gao, 2002; Fung, Lee, and Leung, 2000; Newell et al., 2005; Chau et al., 2009).

\section{METHODOLOGY}

\subsection{HYPOTHESES}

Since Akerlof's (1970) seminal paper, many studies have applied the idea of asymmetric information to explain different phenomena in the financial markets. In line with the theoretical analysis of Cheung and Lee (1995), Fuerst (1998), Blass and Yafeh (2001), Yang and Lau (2010), we posit that firms with higher unobserved quality are more likely to conduct IPOs in a stock market with less information asymmetry in order to signal their better quality. As discussed in Introduction, information in Hong Kong's stock market is less asymmetric than that in mainland China's because the former has a more mature legal system with stringent listing rules and enforcement. In particular, the strict requirements of information disclosure and due diligence in Hong Kong impose a higher cost to lower quality firms. These conditions make a separating equilibrium possible and leads to our first hypothesis:

Hypothesis 1: Firms with higher unobserved quality are more likely to conduct IPOs in Hong Kong than in mainland China.

Another implication (or benefit) from using IPO location as a quality signal is that firms with higher unobserved quality should enjoy a higher IPO offer price in Hong Kong than in mainland China. However, none of the firms in our sample had dual listings, so this implication can only be indirectly tested through examining their underpricing ratios. According to the IPO underpricing literature (e.g., Welch, 1989; Allen and Faulhaber, 1989; Boulton et al., 2011), a good quality firm may use IPO underpricing to reveal its unobserved quality when there exists asymmetric information between firms and investors. Give that the Hong Kong stock market 
has a more mature legal system with stringent listing rules and enforcement, there should be less asymmetric information in Hong Kong than in mainland China. We therefore expect more underpricing in the latter as stated in the following hypothesis:

Hypothesis 2: The degree of IPO underpricing in mainland China is larger than that in Hong Kong.

\subsection{DATA}

We targeted firms that: 1) were floated on the mainland or Hong Kong stock exchanges from 1992 to 2008 and 2) had their core business in the mainland (not Hong Kong) real estate market three years before and after their IPOs. We collected IPOs up to 2008 in order to allow sufficient post-IPO data for analysis. The focus on real estate enables us to use property price indices to account for any change in property market sentiment that may affect a firm's IPO location choice. However, a few real estate firms that had highly diversified business during their IPOs (e.g. China Vanke) were excluded. Our final sample contained 57 real estate firms: 29 listed in mainland China and 28 in Hong Kong.

For each firm in the data set, we collected data on their characteristics for the three years before and after their IPOs. Pre-IPO firm characteristics, such as asset size, annual profits, state ownership, and capital structure, were identified from IPO prospectuses. Post-IPO firm characteristics were collected from various sources. First, market information, such as stock prices and exchange rates, was obtained from DataStream. Second, we extracted operational performances, such as total assets, liabilities, and profits, from the annual reports of each firm. The data will be used to construct ex post measures of firm performance, which are used as proxies for a firm's unobserved quality before IPOs. All data dominated in Hong Kong Dollars was converted into RMB. 
To control for the direct property market conditions in mainland China, we used the property price index constructed by DTZ, a major international property consultancy in Asia. It is a valuation-based index measuring residential and commercial property price trends in Beijing, Shanghai, Guangzhou, and Shenzhen, which are the four most well developed real estate markets in mainland China.

\subsection{MODEL ON IPO LOCATION CHOICE}

To test Hypothesis 1, we used abnormal stock and profit returns as proxies for a firm's unobserved quality. Intuitively, as long as the capital market is weakly efficient, stock prices should reflect any public information on a firm, while private information would not be revealed to investors until after these firms have demonstrated their superior performance. Given this logic, we developed a two-step approach to analyzing IPO location choice.

First, we constructed three different proxies for a firm's unobserved quality: ${ }^{8}$

1) Abnormal profit returns: we ran a regression across firms with post-IPO returns on assets (ROA) against several determinants of operational performance, including state ownership, post-IPO gearing ratio, and post-IPO property market return. Post-IPO ROA is the average annual income per total assets during the three years after the IPO. It is a measure of a firm's gross operating performance. State ownership is a dummy variable that equals 1 if the firm is state-owned and 0 if otherwise. It captures any performance difference between state and privately owned firms. Post-IPO gearing ratio is the average liabilities/assets ratio in the three years after the IPO. It controls for any effect of capital structure on operating performance.

\footnotetext{
${ }^{8}$ These ex post performance measures may contain measurement errors and cause estimation bias in subsequent regression analysis. Nevertheless, they are the best measures available, as pre-IPO data is limited and reliable ex ante measures cannot be constructed.
} 
Post-IPO property market return is measured from the DTZ property price index. It controls for performance difference due to market-wide changes in the property price level within three years after the IPO. The residuals from the regression are defined as the abnormal profit return, which represents a firm's operating performance relative to its peers.

2) Sharpe ratio: it is a standard measure of abnormal returns, which is defined as:

$$
\text { Sharpe Ratio }=\frac{\text { Mean of }\left(\mathrm{r}-r_{M}\right)}{\text { Standard Deviation of }\left(\mathrm{r}-r_{M}\right)}
$$

where $r$ is the firm's stock return and $r_{M}$ is the return of a benchmark portfolio. The mean and standard deviation are based on monthly stock returns of each firm in the three years following its IPO. Since the firms are listed in different stock markets, we used two different benchmark portfolios: (1) the monthly returns of the stock market in which the firm is listed; (2) the weighted monthly returns of all three stock market indices (Hong Kong, Shanghai, and Shenzhen), with the respective total market value as the weight. We also adjusted the market value by the corresponding exchange rate between the HKD and RMB.

3) Jensen's $\alpha$ : it is another standard measure of abnormal returns used in the finance literature. A conventional way to calculate it is based on the Capital Asset Pricing Model (CAPM). We ran the following regression for each firm using its monthly stock returns within three years after its IPO:

$$
r-r_{f}=\alpha+\beta\left(r_{M}-r_{f}\right)
$$

where $r_{f}$ is the risk free rate, $\beta$ is the firm's beta, and $\alpha$ is Jensen's $\alpha$. In the calculation, we used the interest rate of a three-month bank deposit as the risk-free rate. Similar to the construction of the Sharpe Ratio, we used the monthly returns of the corresponding stock market index and the weighted monthly returns of all three stock market indices respectively 
as the benchmark portfolio.

In the second step, we applied the Probit model to explain IPO location choice by each of the above proxies for unobserved quality and other control variables:

$$
\operatorname{Prob}(M=1 \mid X)=\emptyset(\theta X)
$$

where $M$ is an IPO location dummy, which equals 1 if a firm is listed in mainland China and 0 if it is listed in Hong Kong; $\varnothing$ is the cumulative density function of the standard normal distribution; $\theta$ is a vector of the coefficients to be estimated; and $X$ is a vector that includes the proxy for unobserved quality as well as a set of control variables.

Our key interest is the coefficient of unobserved firm quality variable. According to Hypothesis 1, this coefficient should be negative if firms with better unobserved quality are more likely to conduct their IPOs in Hong Kong than in mainland China.

Three control variables in Equation (2) are the observed firm characteristics that could affect a firm's IPO location choices. First, the average ROA for each firm during the three years before its IPO (pre-IPO profit return) is used to control for the observed operating performance of each firm. If asymmetric information exists, such information is deemed less reliable by investors and may have limited influence on a firm's IPO location choice. Second, the average liabilities/assets ratio during the three years before IPO (pre-IPO gearing ratio) measures the capital structure of each firm. A highly levered firm that needs flexibility in subsequent fund-raising activities may prefer Hong Kong because of its better access to global funds and the absence of capital or exchange control. On the other hand, the use of debt could be a positive signal of firm quality and reduce the marginal benefit of listing in a reputable market. Third, whether a firm is a state or privately owned is captured by a state ownership dummy. State-owned enterprises may prefer listing in the mainland market of which the 
government has better control.

Another control variable is related to stock market sentiment. When choosing their IPO locations, firms may compare the Hong Kong and mainland stock markets and prefer a location with relatively better stock market performance. Thus, we further control for the relative performance of the stock markets in Hong Kong and mainland China by using a variable measuring the return difference between the two markets in the year before IPO (stock market relative return).

The final control variable is the growth of the property price index (Property market return). We expect that when the direct property market performs well, firms are more likely to conduct IPOs in mainland China instead of in Hong Kong. The reason is one of information discovery: local investors in mainland China can obtain first-hand information about the direct market more accurately and more quickly through most recent property transactions or local real estate agents. Such information is usually not directly available to foreign (including Hong Kong's) investors until after some time when such information is aggregated and disseminated as a market report or price index. When prices in the direct market are rising, local investors know first and are more willing to buy stocks of real estate firms than foreign investors. On the other hand, when prices in the direct market are dropping, local investors know first and show less interest in buying stocks of real estate firms than foreign investors. Therefore, we use the growth of the property price index in the two years before IPO to control for effects arising from information discovery through the direct market. A higher growth rate should induce firms to conduct IPOs in mainland China.

\subsection{MODEL ON IPO UNDERPRICING}

As discussed in the Hypotheses section, firms with higher unobserved quality should enjoy a higher IPO offer price in Hong Kong than in mainland China. At the same time, firms 
may also use IPO underpricing to signal unobserved quality to potential investors. Both arguments imply, ceteris paribus, greater IPO underpricing in mainland China where the problem of information asymmetry is more serious. As is standard in the literature, underpricing is measured by this ratio:

$$
\text { Underpricing ratio }=\frac{\text { Closing Price }- \text { Offer Price }}{\text { Offer Price }}
$$

where the offer price is the price set by each firm before listing and the closing price is the closing stock price on the listing day. A higher underpricing ratio means the shares are initially underpriced by the firm.

After defining the underpricing ratio, we used the following regression model to test Hypothesis 2:

$$
\text { Underpricing ratio }=\gamma_{0}+\gamma_{1} M+\gamma Z
$$

where $M$ is the mainland dummy as defined before and $\mathrm{Z}$ is a vector of control variables. According to Hypothesis 2, the coefficient of $M$ is positive if the magnitude of underpricing is larger in the mainland market.

$Z$ in Equation (3) contains five control variables, some of which have been defined before. First, a state ownership dummy is used to control for the performance uncertainty associated with state-owned enterprises, which may be less operationally efficient but enjoy a closer relationship with the government. Whether its coefficient should be positive or negative is an empirical question. Second, pre-IPO gearing ratio could be taken as a signal of firm quality because according to the pecking order theory, firms with positive net present value projects should have preferred debt financing before issuing equity. Moreover, more debts would reduce free cash flow and alleviate the agency problem between shareholders and the manager. 
A firm with more debts should thus underprice less. Third, stock market return before IPO controls for the stock market conditions a month before listing, which may affect how the firm sets its offer price. Better pre-IPO market conditions should enable the firm to set a higher offer price and hence a lower underpricing ratio. Fourth, stock market return on the IPO day controls for stock market conditions on the listing date. Better market conditions on the IPO day should raise the closing price as well as the underpricing ratio. Finally, abnormal profit return, Sharpe ratio, and Jensen's $\alpha$, as described in Section 3.3, are used separately to control for unobserved firm quality. To signal their unobserved quality to investors, high quality firms should underprice more than low quality firms. However, these performance variables may be correlated with a firm's IPO location $(M)$, if Hypothesis 1 is correct. We will run regressions based on Equation (3) with and without these proxies to check robustness.

\section{EMPIRICAL RESULTS}

\subsection{PRELIMINARY STATISTICS}

Before presenting the regression results, we first compare the descriptive statistics of the mainland developers listed in mainland China and Hong Kong. Table 1 shows their post-IPO performance measured by the profit return, abnormal profit return, Sharpe ratio, and Jensen's $\alpha$. Developers listed in the mainland (0.0714) had a higher mean profit return than those listed in Hong Kong (0.0616). However, on the basis of mean abnormal profit return and Sharpe ratio where risk factors are adjusted, Hong Kong-listed developers outperformed the mainlandlisted ones. In particular, the mean abnormal profit return of mainland-listed developers was negative (-0.0020), compared to a positive value of 0.0025 for the Hong Kong-listed ones. Listings in Hong Kong also showed a higher mean Sharpe ratio, especially based on the weighted stock market indices. The results from Jensen's $\alpha$ are mixed, depending on whether 
the weighted or un-weighted version of the stock market indices is used. Nevertheless, the difference in mean Jensen's $\alpha$ is quite small, as compared to its standard deviation. On the basis of unconditional mean (without controlling for other determinants of IPO location), we find no clear pattern that mainland or Hong Kong-listed developers had consistently better post-IPO performance.

Table 2 shows the degree of IPO underpricing of developers based the underpricing ratio. The average underpricing ratio of developers listed in mainland China (4.9552) was much larger than that in Hong Kong (0.117). An excessively high underpricing ratio in the mainland is consistent with findings in other studies and explainable by state ownership, high risk of new issues, and investment opportunities (e.g. Mok and Hui, 1998; Su and Fleisher, 1999).

Descriptive statistics of the control variables used in Equations (2) and (3) are shown in Table 3. Mainland-listed developers had higher average profit return, both pre and post-IPO, than Hong Kong-listed developers; yet, IPO appears to worsen the former's operating performance while improving the latter's. Mainland-listed developers had lower average gearing ratios than the Hong Kong's counterparts, and both reduced their leverage after IPO. The mainland property market generally performed better when developers chose to list in the mainland than when they were listed in Hong Kong. The same is true for stock market returns both before IPO and on the listing day. All these firm and market characteristics will be controlled for when we analyze IPO location choices and IPO underpricing.

\subsection{DETERMINANTS OF IPO LOCATION}

To test Hypothesis 1, we used the probit model in Equation (2) to explain firms' IPO location by each proxy for unobserved firm quality and other possible determinants, including pre-IPO profit return, pre-IPO gearing ratio, state ownership, stock market relative return, and

property market return. Table 4 presents the results using the abnormal profit return as the 
proxy for unobserved quality, whereas Table 5 presents the results using the Sharpe ratio and Jensen's $\alpha$. No matter which proxy is used, the results are indeed highly similar. The McFadden $\mathrm{R}^{2}$ is above $60 \%$ in all cases.

First, and most importantly, the coefficients of all the proxies for unobserved firm quality, including the abnormal profit return, Sharpe ratio and Jensen's $\alpha$, are negative and significant at the 5\% level. That is, controlling for other IPO location determinants, developers with better unobserved quality were more likely to conduct IPOs in Hong Kong instead of mainland China. This confirms Hypothesis 1, which posits that there exists asymmetric information between firms and investors and conducting IPOs in Hong Kong may serve as a positive signal for unobserved firm quality. As mentioned before, the Hong Kong stock exchange has more stringent information disclosure requirements and law enforcement such that low quality firms would find it too costly to imitate high quality firms in floating their shares in Hong Kong. Low quality firms would rather conduct their IPOs in mainland China to prevent revelation of too much information. Note that the use of different benchmark portfolios for Sharpe ratio and Jensen's $\alpha$ only changes the coefficients slightly, while their sign and significance remain the same.

Second, property market return (before IPO) is an important determinant of IPO location, as its coefficient is positive and significant at the $5 \%$ level in all cases. That is, when the mainland property market performed well, developers tended to conduct IPOs in mainland China instead of in Hong Kong. This is because local investors in mainland China, who have direct access to changing local property market conditions, would adjust their valuation of a developer's IPO more quickly than foreign investors. Local investors' direct access could come from their direct participation in trading properties or the most recent transactions reported by real estate agents and local news. In contrast, most foreign investors could only rely on 
aggregate and delayed information from market reports. As a result, when the property market turns good, developers prefer to list in mainland China so as to take advantage of local investors' higher valuation. Likewise, when the property market turns bad, developers tend to list in Hong Kong to enjoy foreign investors' higher valuation of their shares.

The third important determinant of IPO location is pre-IPO gearing ratio, whose coefficient is negative and highly significant in all cases. As mentioned before, developers with a higher level of debt may prefer to list in Hong Kong because an easy access to global capital and the absence of exchange control can give them greater flexibility in any subsequent fund-raising activities, e.g., to repay the debt or finance new projects. This flexibility apparently outweighed any signaling benefit from the use of debt when developers chose their IPO locations.

The fourth determinant is state ownership. In all cases, its coefficient is positive and significant, indicating that state-owned developers were more likely to conduct IPOs in the mainland stock market. This could be due to two reasons. Politically, listing in the mainland allows the Chinese Government to have more control over their companies. Another argument for listing in the mainland is that foreign investors may be less familiar with the political structure of state-owned enterprises and tend to undervalue the shares of these companies.

Two control variables, namely pre-IPO profit return and stock market relative return, are found not significant. The insignificance of the pre-IPO profit return actually reinforces our argument that asymmetric information exists and a high profit return does not necessarily imply good firm quality. Unobserved quality is revealed not by pre-IPO profit returns but by the IPO location. The insignificance of stock market relative return suggests that the performance difference between the Hong Kong and mainland stock markets did not matter in the choice of IPO location. One possible reason is that movements of the two markets were highly correlated, 
especially in the past decade.

\subsection{DETERMINANTS OF IPO UNDERPRICING}

To test Hypothesis 2, we used the regression model in Equation (3) to explain firms' underpricing ratio by their IPO locations and other possible determinants, including pre-IPO gearing ratio, stock market return before IPO, stock market return on the IPO day, state ownership, and the three proxies of unobserved firm quality. Table 6 presents the results, all with an $\mathrm{R}^{2}$ value of approximately $30 \%$. The results are similar irrespective of whether unobserved quality is included and which proxy of unobserved quality is used.

As expected, the coefficient of the mainland dummy is positive and significant, confirming Hypothesis 2 that mainland-listed developers showed a larger degree of IPO underpricing than Hong Kong-listed developers. This comes as a reward to good quality firms that invested in location signaling. At the same time, the stringent requirements in the Hong Kong stock market also make information more symmetric, so firms listed in Hong Kong do not have to greatly underprice their shares in order to signal quality. In contrast, in a market where information is less symmetric, mainland-listed firms have to rely on underpricing to distinguish between firms.

The second determinant of IPO underpricing is pre-IPO gearing ratio. Its coefficient is negative and significant, indicating that developers with more leverage underpriced less during their IPOs. This is consistent with the use of debts (as opposed to equity) to convey a positive signal to investors, which allows firms with more debts to underprice less.

The third determinant is the stock market return in the month before IPO. Its negative and significant coefficient shows that developers underpriced less when the stock market performed well prior to IPO. Observing a growing stock market, a higher offer price is set, resulting in a 
lower underpricing ratio.

The remaining three control variables are not significant. The stock market return on the IPO day had little impact on the underpricing ratio, probably because the stock market return before IPO has already captured most of the market risk during the IPO process. The insignificance of the state ownership dummy can be interpreted as a tradeoff between uncertainty in state-owned enterprises' operational efficiency and their superior role in controlling state resources. The proxies of unobserved quality, namely abnormal profit return, Sharpe ratio, and Jensen's $\alpha$, are not significantly associated with the underpricing ratio. This does not mean that underpricing does not reveal unobserved quality; rather, the effect of the unobserved quality proxies might have been taken away by the location dummy, as a significant relationship between them was established in Hypothesis 1. Suffice it to say is that IPO location has adequately captured the unobserved quality that is needed to explain IPO underpricing.

\section{CONCLUSION}

We investigated how developers use IPO location to reveal their unobserved quality and how IPO location affects the degree of IPO underpricing. By using post-IPO abnormal stock returns (the Sharpe ratio and Jensen's $\alpha$ ) and abnormal profit returns as the proxies for unobserved quality, we found that higher quality firms were more likely to conduct their IPOs in Hong Kong rather than mainland China. This is consistent with the signaling theory - good firms tend to signal their quality in a stock market with more stringent rules so that other firms cannot imitate. In addition, we found that better local property market performance, lower leverage, and state ownership, were significant factors driving developers to list in the mainland instead of Hong Kong. 
A further test on IPO underpricing reveals that mainland-listed developers underpriced their shares more than Hong Kong-listed developers. This is again consistent with the signaling theory - firms listed in a more symmetric information environment like Hong Kong's need not greatly underprice their shares in order to signal quality. Other determinants of IPO underpricing were gearing ratio and stock market performance.

Due to our small sample size, it is not possible to further test if IPO location goes beyond a pure quality signal (Spence, 1973) by adding ex post productivity to a firm. While the descriptive statistics in Table 2 reveal a growth of profit returns for firms listed in Hong Kong but not for those listed in the mainland, the differences were not significant. A longer sample period is needed to capture any productivity increase after IPO, which we have to leave for further search.

\section{ACKNOWLEDGEMENTS}

We are grateful to the participants of the NUS-MIT-Maastricht Real Estate symposium, especially our discussant KG Lim, for their useful comments. We would also like to thank Charles Leung for his valuable comments on an early version of this paper. This project was supported by the General Research Fund (Project Reference: HKU 755210). 


\section{REFERENCES}

Akerlof, G.A. 1970. The market for "lemons": Qualitative uncertainty and the market mechanism. Quarterly Journal of Business and Economics 84(3): 488-500.

Allen, F. and G. Faulhaber. 1989. Signalling by underpricing in the IPO market. Journal of Financial Economics 23(2): 303-323.

Baker, H.K., J.R. Nofsinger and D. G. Weaver. 2002. International cross-listing and visibility. The Journal of Financial and Quantitative Analysis 37(3): 495-521.

Bhattacharya, S. 1979. Imperfect information, dividend policy and "The bird in the hand" fallacy. Bell Journal Economics 9: 1225-1243.

Blass, A. and Y. Yafeh. 2001. Vagabond shoes longing to stray: Why foreign firms list in the United States. Journal of Banking and Finance 25(3): 555-572.

Boulton, T. J., S. B. Smart. and C. J. Zutter. 2011. Earnings Quality and International IPO Underpricing. Accounting Review, 86 (2): 483-505.

Brickley, J.A. 1983. Shareholder wealth, information signaling and the specially designated dividend: An empirical study. Journal of Financial Economics 12(2): 187-209.

Chau, K.W., K. McKinnell., S.K. Wong, Q. Wei and G. Newell. 2010. Impact of corporate governance structures on the relationship between direct and indirect real estate in China. Journal of real Estate portfolio management 16(1): 9-19.

Chemmanur, T. 1993. The pricing of Initial public offerings: A dynamic model with information production. Journal of Finance 48(1): 285-304.

Cheung, S., Lee, J. 1995. Disclosure environment and listing on foreign stock exchanges. 
Journl of Banking and Finance 19(2): 347-362.

Doidge, C. 2004. US cross-listings and the private benefits of control: evidence from dual-class firms. Journal of Financial Economics 72(3): 519-553.

Grinblatt, M., and C. Y. Hwang. 1989. Signalling and the pricing of unseasoned new issues, Journal of Finance 44 (2): 393-420.

Fung, H.G., W. Lee and W.K Leung. 2000. Segmentation of the A-and B-share Chinese equity markets. Journal of Financial Research 23(2): 179-195.

Fuerst, O. 1998. A theoretical analysis of the investor protection regulations argument for global listing of stocks. Working Paper, Yale University Yale School of Management, New Haven

Gao, S. 2002. China stock market in a global perspective. Dow Jones Indexes, 1-48.

Harris, M and A. Raviv. 1985. A sequential signaling model of convertible debt call policy. Journal of Finance 40(5): 1263-1281.

Ibbotson, R.G. 1975. Price performance of common stock new issues. Journal of Financial Economics 2(3): 235-272.

Ibbotson, R.G., J.L. Sindelar and J.R. Ritter. 1988. Initial public offerings. Journal of Applied Corporate Finance 1(2): 37-45.

Kennedy, D.B., Sivakumar, R. and Vetzal, K.R. 2006. The implications of IPO underpricing for the firm and insiders: tests of asymmetric theories. Journal of Empirical Finance 13, 49-78.

Lang, L.H.P. and R.H. Litzenberger. 1989. Divident announcements, cash flow signaling vs. 
free cash flow hypothesis? Journal of Finance 24(1): 181-191.

Leland, H.E. and D.H. Pyle. 1977. Informational asymmetries, financial structure and financial intermediation, The Journal of Finance 32(2): 371-387.

Merton, R.C. 1987. A simple model of capital market equilibrium with incomplete information. The Journal of Finance 42(3): 483-510.

Mok, H.M.K. and Y.V. Hui. 1998. Underpricing and aftermarket performance of IPOs in Shanghai, China. Pacific-Basin Finance Journal 6(5): 453-474.

Myers, S.C. and N. Majluf. 1984. Corportate financing and investment decisions when firms have informaton that investors do not have. The Journal of Finance 13(2): 187-211.

Newell, G., K.W. Chau, S.K. Wong and K. McKinnell. 2005. Dynamics of the direct and indirect real estate markets in China. Journal of real Estate portfolio management 11(3): 263-279.

Ofer, A.R. and A. Natarajan. 1987. Convertible call policies: An empirical analysis of an information-signaling hypothesis. The Journal of Finance 19(1): 91-108.

Ofer, A.R. and D. Siegel. 1987. Corporate financial policy, information and Market expectations: An empirical investigation of dividends. The Journal of Finance 42(4): 889-911.

Ritter, J.R. 1984. The "hot issue" market of 1980. The Journal of Business 57(2): 215-240.

Ritter, J.R. 1991. The long-run performance of initial public offerings. Journal of Finance 46(1): $3-27$.

Spence, A.M. 1973. Job market signaling. Quarterly Journal of Economics 87(3): 355-374. 
Su, D. and B.M. Fleisher. 1999. An empirical investigation of underpricing in Chinese IPOs. Pacific-Basin Finance Journal 7(2): 173-202.

Tian, L. 2011. Regulatory underpricing: determinants of Chinese extreme IPO returns. Journal of Empirical Finance 18, 78-90.

Welch, I. 1989. Seasoned offerings, imitation costs, and the underpricing of initial public offerings. Journal of Finance 44(2): 421-449.

Yang, T. and Lau, S.T. 2010. An empirical investigation of Yankee stock offerings. Review of Quantitaive Financ and Accouting 34(3): 351-370 
Table 1: Descriptive statistics of post-IPO performance

\begin{tabular}{lcccc}
\hline & \multicolumn{2}{c}{ Mean } & \multicolumn{2}{c}{ Standard deviation } \\
\cline { 2 - 5 } & Mainland & Hong Kong & Mainland & Hong Kong \\
\hline Profit return & 0.0714 & 0.0616 & 0.0421 & 0.0199 \\
Abnormal profit return & -0.0020 & 0.0025 & 0.0328 & 0.0195 \\
Sharpe ratio (UW) & 0.0297 & 0.0347 & 0.1649 & 0.1269 \\
Sharpe ratio (W) & $-2.47 \mathrm{E}-05$ & 0.0182 & 0.1701 & 0.0920 \\
Jensen's $\alpha$ (UW) & 0.0066 & 0.0059 & 0.0158 & 0.0205 \\
Jensen's $\alpha(\mathrm{W})$ & 0.0068 & 0.0070 & 0.0189 & 0.0194 \\
\hline
\end{tabular}

1. Profit return is the post-IPO ROA, whereas abnormal profit return is the residual from a cross-sectional regression of post-IPO ROA on state ownership, post-IPO gearing ratio, and post-IPO property market returns (see Section 3.3).

2. "UW" and "W" refer to the use of different benchmark portfolios. "UW" uses the (un-weighted) stock market index in which the firm is listed. "W" uses the weighted average index of all three stock exchanges (Hong Kong, Shanghai, and Shenzhen) where the respective total market capitalization is taken as the weight.

Table 2: Descriptive statistics of IPO underpricing

\begin{tabular}{lcccc}
\hline \hline & \multicolumn{2}{c}{ Mean } & \multicolumn{2}{c}{ Standard deviation } \\
\cline { 2 - 5 } & Mainland & Hong Kong & Mainland & Hong Kong \\
\hline Underpricing ratio & 4.9552 & 0.117 & 7.2956 & 0.3907 \\
\hline $\begin{array}{l}\text { 1. Underpricing ratio is the percentage difference between the first-day closing price and the IPO offer price } \\
\text { (see Section 3.4). }\end{array}$ \\
\hline
\end{tabular}

Table 3: Descriptive statistics of the firm and market characteristics

\begin{tabular}{lcccc}
\hline \hline & \multicolumn{2}{c}{ Mean } & \multicolumn{2}{c}{ Standard deviation } \\
\cline { 2 - 5 } & Mainland & Hong Kong & Mainland & Hong Kong \\
\hline Pre-IPO profit return & 0.0736 & 0.0596 & 0.0389 & 0.0405 \\
Post-IPO profit return & 0.0714 & 0.0616 & 0.0421 & 0.0199 \\
Pre-IPO gearing ratio & 0.5532 & 0.7599 & 0.1661 & 0.1463 \\
Post-IPO gearing ratio & 0.4733 & 0.5354 & 0.1461 & 0.1427 \\
Property market return (before IPO) & 0.1272 & 0.0643 & 0.1424 & 0.0870 \\
Stock market return (before IPO) & 0.0709 & 0.0314 & 0.1392 & 0.0773 \\
Stock market return (on the IPO day) & 0.0088 & 0.0003 & 0.0324 & 0.0148 \\
\hline
\end{tabular}




\section{Table 4: IPO location and abnormal profit returns}

\begin{tabular}{|c|c|}
\hline & $\operatorname{Prob}(M=1)$ \\
\hline \multirow[t]{3}{*}{ Abnormal profit return } & -34.6525 \\
\hline & $(-2.0281)^{* *}$ \\
\hline & {$[-2.8980]^{* * *}$} \\
\hline \multirow[t]{3}{*}{ Property market return } & 13.2256 \\
\hline & $(2.8266) * * *$ \\
\hline & {$[2.3930]^{* *}$} \\
\hline \multirow[t]{3}{*}{ Stock market relative return } & 0.6273 \\
\hline & $(1.0308)$ \\
\hline & {$[1.1488]$} \\
\hline \multirow[t]{3}{*}{ Pre-IPO profit return } & 1.4486 \\
\hline & $(0.1749)$ \\
\hline & {$[0.2290]$} \\
\hline \multirow[t]{3}{*}{ Pre-IPO gearing ratio } & -8.7422 \\
\hline & $(-2.9953)^{* * *}$ \\
\hline & {$[-3.2571]^{* * *}$} \\
\hline \multirow[t]{3}{*}{ State ownership dummy } & 2.0171 \\
\hline & $(2.8334) * * *$ \\
\hline & {$[2.3067]^{* *}$} \\
\hline \multirow[t]{3}{*}{ Constant } & 4.0952 \\
\hline & $(2.0097) * *$ \\
\hline & {$[2.2632] * *$} \\
\hline McFadden $\mathrm{R}^{2}$ & 0.6059 \\
\hline Percent correctly predicted & 91.1 \\
\hline \multicolumn{2}{|c|}{$\begin{array}{l}\text { 1. This table reports the estimation for Equation }(2) \text { : } \operatorname{Prob}(M=1 \mid X)=\emptyset(\theta X) \text {, where } \varnothing \text { is } \\
\text { the cumulative density function of the standard normal distribution, } M \text { is the mainland } \\
\text { dummy (mainland }=1 \text {; Hong Kong }=0 \text { ) and } X \text { is a vector that includes the proxy for } \\
\text { unobserved quality and other control variables. } \\
2 \text {. The z-statistics are presented in parentheses, and the White heteroskedasticity-robust z- } \\
\text { statistics are presented in squared brackets. Significance at the } 10 \%, 5 \% \text {, and } 1 \% \text { levels is } \\
\text { indicated by } * * * \text {, and } * * * \text {, respectively. } \\
3 \text {. We tested for multicollinearity using the variance inflation factor (VIF) analysis } \\
\text { developed by Neter et al. (1996). In all regressions, the magnitude of the VIF is less than } \\
5 \text {, implying no significant parameter distortion caused by multicollinearity. }\end{array}$} \\
\hline
\end{tabular}


Table 5: IPO location and abnormal stock returns

\begin{tabular}{|c|c|c|c|c|}
\hline $\operatorname{Prob}(M=1)$ & (i) & (ii) & (iii) & (iv) \\
\hline Sharpe ratio (UW) & $\begin{array}{l}-6.7291 \\
(-2.0800)^{* *} \\
{[-2.5854]^{* * *}}\end{array}$ & & & \\
\hline Sharpe ratio $(\mathrm{W})$ & & $\begin{array}{l}-6.5762 \\
(-2.0323)^{* *} \\
{[-2.4381]^{* *}}\end{array}$ & & \\
\hline Jensen's alpha (UW) & & & $\begin{array}{l}-32.2258 \\
(-2.1460)^{* *} \\
{[-2.0031]^{* *}}\end{array}$ & \\
\hline Jensen's alpha (W) & & & & $\begin{array}{l}-40.0831 \\
(-2.3284)^{* *} \\
{[-2.6861]^{* * *}}\end{array}$ \\
\hline Property market return & $\begin{array}{l}16.6829 \\
(2.5213)^{* *} \\
{[2.7552]^{* * *}}\end{array}$ & $\begin{array}{l}15.5585 \\
(2.5426)^{* *} \\
{[2.8315]^{* *}}\end{array}$ & $\begin{array}{l}12.5575 \\
(2.4094)^{* *} \\
{[2.2501]^{* *}}\end{array}$ & $\begin{array}{l}13.7193 \\
(2.4991)^{* *} \\
{[2.4275]^{* *}}\end{array}$ \\
\hline Stock market relative return & $\begin{array}{l}1.0519 \\
(1.2281) \\
{[1.3356]}\end{array}$ & $\begin{array}{l}0.5381 \\
(0.7705) \\
{[0.7417]}\end{array}$ & $\begin{array}{l}0.5183 \\
(0.7517) \\
{[0.7383]}\end{array}$ & $\begin{array}{l}0.4776 \\
(0.6734) \\
{[0.6643]}\end{array}$ \\
\hline Pre-IPO profit return & $\begin{array}{l}5.5526 \\
(0.5389) \\
{[0.6812]}\end{array}$ & $\begin{array}{l}2.754 \\
(0.2812) \\
{[0.3574]}\end{array}$ & $\begin{array}{l}1.5425 \\
(0.1607) \\
{[0.2378]}\end{array}$ & $\begin{array}{l}2.8 \\
(0.2830) \\
{[0.4012]}\end{array}$ \\
\hline Pre-IPO gearing ratio & $\begin{array}{l}-8.7944 \\
(-2.5815)^{* * *} \\
{[-3.6155]^{* * *}}\end{array}$ & $\begin{array}{l}-9.1075 \\
(-2.6262)^{* * *} \\
{[-3.6513]^{* * *}}\end{array}$ & $\begin{array}{l}-9.4372 \\
(-3.0612)^{* * *} \\
{[-3.7232]^{* * *}}\end{array}$ & $\begin{array}{l}-9.9801 \\
(-2.9037)^{* * *} \\
{[-3.7788]^{* * *}}\end{array}$ \\
\hline State ownership dummy & $\begin{array}{l}2.0969 \\
(2.5841)^{* * *} \\
{[2.9141]^{* * *}}\end{array}$ & $\begin{array}{l}2.282 \\
(2.5776)^{* * *} \\
{[3.1640]^{* * *}}\end{array}$ & $\begin{array}{l}1.8145 \\
(2.6438)^{* * *} \\
{[2.5822]^{* * *}}\end{array}$ & $\begin{array}{l}2.1722 \\
(2.7398)^{* * *} \\
{[3.0994]^{* * *}}\end{array}$ \\
\hline Constant & $\begin{array}{l}4.301 \\
(1.7783) * * \\
{[2.4714]^{* *}}\end{array}$ & $\begin{array}{l}4.3645 \\
(1.8344) * * \\
{[2.4528]^{* *}}\end{array}$ & $\begin{array}{l}5.1525 \\
(2.3173) * * * \\
{[3.1040] * * *}\end{array}$ & $\begin{array}{l}5.3408 \\
(2.2009) * * * \\
{[3.0039] * * *}\end{array}$ \\
\hline McFadden $\mathrm{R}^{2}$ & 0.6437 & 0.6317 & 0.6088 & 0.6398 \\
\hline Percent correctly predicted & 88.9 & 86.7 & 88.9 & 91.1 \\
\hline
\end{tabular}

1. This table reports the estimation for Equation (2): $\operatorname{Prob}(M=1 \mid X)=\emptyset(\theta X)$, where $\varnothing$ is the cumulative density function of the standard normal distribution, $M$ is the mainland dummy (mainland=1; Hong Kong=0) and $X$ is a vector that includes the proxy for unobserved quality and other control variables.

2. The z-statistics are presented in parentheses, and the White heteroskedasticity-robust z-statistics are presented in squared brackets. Significance at the $10 \%, 5 \%$, and $1 \%$ levels is indicated by *,**, and ***, respectively.

3 . We tested for multicollinearity using the variance inflation factor (VIF) analysis developed by Neter et al. (1996). In all regressions, the magnitude of the VIF is less than 5, implying no significant parameter distortion caused by multicollinearity.

4. "UW" and "W" refer to the use of different benchmark portfolios. "UW" uses the (un-weighted) stock market index in which the firm is listed. "W" uses the weighted average index of all three stock exchanges (Hong Kong, Shanghai, and Shenzhen) where the respective total market capitalization is taken as the weight. 
Table 6: Initial underpricing and IPO location

\begin{tabular}{lllll}
\hline \hline Underpricing ratio & (i) & (ii) & (iii) & (iv) \\
\hline Mainland dummy (M) & 3.1455 & 3.1299 & 3.1791 & 3.1717 \\
& $(2.0428)^{* *}$ & $(1.9867)^{*}$ & $(2.0322)^{* *}$ & $(2.0234)^{* *}$ \\
Pre-IPO gearing ratio & -7.8708 & -7.8992 & -7.8786 & -7.8143 \\
& $(-2.0506)^{* *}$ & $(-1.9959)^{*}$ & $(-2.0315)^{* *}$ & $(-2.0035)^{*}$ \\
Stock market return before IPO & -11.4247 & -11.4217 & -11.6182 & -11.5018 \\
& $(-1.9613)^{*}$ & $(-1.8875)^{*}$ & $(-1.9491)^{*}$ & $(-1.9451)^{*}$ \\
Stock market return on the IPO & -7.6875 & -7.2221 & -8.0810 & -7.807 \\
day & $(-0.3144)$ & $(0.2877)$ & $(-0.3262)$ & $(-0.3158)$ \\
State ownership dummy & -0.2834 & -0.3018 & -0.2878 & -0.2878 \\
Abnormal profit return & $(-0.2198)$ & $(-0.2279)$ & $(-0.2209)$ & $(-0.2208)$ \\
Sharpe ratio (UW) & & -4.0400 & & \\
Jensen's alpha (UW) & & $(-0.1260)$ & & 0.8562 \\
Constant & & & $(0.2047)$ & \\
& & & & 4.6654 \\
$\mathrm{R}^{2}$ & & & & $(0.1387)$ \\
Adjusted-R & & & 6.4950 \\
\hline
\end{tabular}

1. This table reports the estimation for Equation (3): Underpricing ratio $=\gamma_{0}+\gamma_{1} M+\gamma Z$ where $M$ is the mainland dummy (mainland $=1$; Hong Kong=0) and $Z$ is a vector of control variables.

2. The OLS t-Statistics are presented in parentheses. Significance at the $10 \%, 5 \%$, and $1 \%$ levels is indicated by $*, * *$, and $* * *$, respectively.

3. All the regressions have passed the tests on multicollinearity and heteroskedasticity.

4. "UW" refers to the use of the (un-weighted) stock market index in which the firm is listed as the benchmark portfolio. 